THE ANNALS OF "DUNAREA DE JOS" UNIVERSITY OF GALATI

FASCICLE XV ISSN - 1454 - 9832 - Vol. 2/2019

Article DOI: https://doi.org/10.35219/efms.2019.2.05

\title{
TRAINING AND DEVELOPMENT OF COMMUNICATION SKILLS TO FUTURE SPECIALISTS IN PHYSICAL EDUCATION AND SPORTS
}

\author{
Mariana GIDEI * \\ State University of Physical Education and Sport, Chisinau, \\ 22, A Doga Street., Republic of Moldova, \\ mgidei@mail.ru
}

\begin{abstract}
Communicative skills are the mobilization of a set of resources that are practically manifested by those involved in the interaction and are applied to communicate successfully. Regarding the training of communication skills, we mention the three levels of their acceptance: the taxonomy and the fields assumed by the key European skills; the inner structure of skills as goals: knowledge, abilities, attitudes; university curriculum (including general and specific skills). The purpose of the experiment was to develop communication skills by introducing practical studies into the content of learning (seminars and individual work of students), increasing the value of each student's academic performance, as well as improving the student's relationship within the university collective and developing the competency model in communication needed by the specialist in the field. The research hypothesis: the introduction of practical studies in the seminars and the individual work of the students, through the use of a modern, interactive teaching vision, determines the development of students' communication skills, positive interpersonal relation and improvement of performances and academic success in the subject "Management of Communication in Physical Education and Sports ". The practical-applicative research took place at SUPES, with students from the Sports Faculty in the academic year 2016-2017. The sample of subjects was made up of 28 students, the third year of studies. Methodology of research: pedagogical experiment, systematic observation method, test method, observation method, method of portfolio analysis / materials of students (sheets, posters, papers, case studies, reports, research projects created by them). The result of the research is training and development of students' communication skills in the course "Management of Communication in Physical Education and Sports", by substantiating the application methodology in the learning process, respectively the result of the knowledge, practical skills, including the attitudes trained by communication, which will lead to an increased level of their training.
\end{abstract}

Keywords: physical education, communication, skil.

Introduction. Students and graduates of physical education and sports faculties need communication skills, i.e. the ability to express and interpret thoughts, feelings and facts, both in written and oral, within the whole spectrum of social contexts: professional activity, sports activity, family and leisure time [1]. It is also becoming more and more common that the communication process in the family, school and social environment has begun to degrade more and more. Considering this fact, complemented by the need to develop communication skills and to identify these competences to the specialists in the field, we introduced in the individual seminars and individual activities of students additional requirements in the practical content of the course "Management of Communication in Physical Education and Sports".

The research problem is the formation and development of students' communication skills (Cycle I) within the course "Management of Communication in Physical Education and Sports", by substantiating the methodology of application in the learning process, respectively the product of knowledge, practical skills, and attitudes formed by communication, which will lead to an increased level of training.
The purpose of the experiment was to develop communication skills by introducing practical studies into the content of learning (seminars and individual work of students), increasing the value of each student's academic performance, as well as improving the student's relationship within the university collective and developing the competency model in communication needed by the specialist in the field.

Objectives of the experiment:

- projecting, organizing and conducting didactic approaches to develop students' communication skills and form assertive behavior;

- using the holistic model in organizing didactic activities to stimulate the active and interactive involvement of the student in the process of learning and practical training;

- recording, monitoring and comparing the results obtained by the students in the tests regarding the cognitive and behavioral component;

- analysis of the influences exercised through the application of practical studies in the seminars and in the individual work of the students.

The research hypothesis Introduction of practical studies in the seminars and the individual work of the 


\section{THE ANNALS OF "DUNAREA DE JOS" UNIVERSITY OF GALATI \\ FASCICLE XV ISSN - 1454 - 9832 - Vol. 2/2019}

students, through the use of a modern, interactive teaching vision, determines the development of students' communication skills, positive interpersonal relation and improvement of performances and academic success in the subject "Management of Communication in Physical Education and Sports "of each student.

\section{Methodology of research}

1.The methods used werepedagogical experiment, systematic observation method, test method, questionnaire method, method of analyzing portfolios / materials of students (sheets, posters, papers, case studies, reports, research projects created by them).

The pedagogical experiment (also called the method of observation) was the main method of investigation in our research. This method involves the deliberate production or change of educational phenomena for their in-depth study. Testing the research hypothesis required the organization and development of a series of didactic experiments and three stages: the preexperiment / pretest stage, the experimental stage / the formative experiment and the post-experimental stage / the control / posttest stage.

- in the pre-experimental stage we designed and elaborated the practical part of the content of the university curricula necessary for acquiring communication skills by the students at the end of the study of the subject "Management of communication in physical education and sports", we established the unique sample of subjects involved in this research (14 students in groups 301 and 302), we have determined the level of communication skills of students and their behavioral attitude using the initial evaluation questionnaire as working methods;

- in the experimental stage we introduced the independent variable, respectively we approached the curriculum by capitalizing the practical contents supported by interactive methods, which positively influenced the communication skills, the students' behavior and the results in other study subjects, we applied the tests of knowledge evaluation after each unit of learning;

- in the post-experimental stage, we applied the final evaluation questionnaire, comparing the start and final data, interpreted the results obtained in the knowledge assessment tests, establishing the relevance of the differences between the obtained results, proving the effectiveness of these practical studies introduced in the students' learning process, which confirms the working hypothesis.

2.The sample of subjects used was the unique sample of 28 students, the IIIrd year of study, the specialty Physical Education and Sports.

The content sample was structured around the following indicators:

- self-knowledge;

- written, verbal and non-verbal communication;

- assertive communication;

- way of conflict management.

They have as teaching support practical studies according to the university curriculum in the discipline " Management of Communication in Physical Education and Sports".

The main results

The use of practical content through the application of interactive methods within the discipline "Management of Communication in Physical Education and Sports" aimed at forming professional communication skills to future specialists in the field. In Table 1 we present the practical learning activities and the skills in completing the study of the subject " Management of Communication in Physical Education and Sports".

Table 1. Practical Learning Activities and Skills in Completing the Study of "Management of Communication in Physical Education and Sports"

\begin{tabular}{|l|l|}
\hline \multicolumn{1}{|c|}{ PracticalLearningActivities } & \multicolumn{1}{c|}{ Skills } \\
\hline $\begin{array}{l}\text { The Communication Forms Used Mostly in } \\
\text { Sports Entities }\end{array}$ & $\begin{array}{l}\text { Ability to communicate in writing and oral form within the } \\
\text { sports institution; } \\
\text { The ability to identify relevant gestures in nonverbal } \\
\text { communication. }\end{array}$ \\
\hline Communication tools in sports organizations & $\begin{array}{l}\text { Ability to use the communication tools needed for various } \\
\text { actions (image, promotional materials, open-door days, } \\
\text { neighboring system newspaper, etc.). }\end{array}$ \\
\hline Communication techniques used in sports & $\begin{array}{l}\text { Ability to understand and use broadcasting (electronic media } \\
\text { transmission as a tool of communication policy of sports } \\
\text { organizations). }\end{array}$ \\
\hline Speechinpublic & $\begin{array}{l}\text { Ability to develop and hold a speech on various sporting } \\
\text { events. }\end{array}$ \\
\hline $\begin{array}{l}\text { Approach to critical thinking, formulation of } \\
\text { personal views, expression of ideas, initiative }\end{array}$ & $\begin{array}{l}\text { Ability to think and communicate rationally; } \\
\text { The ability to formulate own arguments in a convincing } \\
\text { manner and to take into account other oral and written views. }\end{array}$ \\
\hline $\begin{array}{l}\text { Distinction between relevant and irrelevant } \\
\text { information depending on a particular context }\end{array}$ & Ability to distinguish relevant and irrelevant information. \\
\hline Drafting texts for a variety of purposes; & Abilit to write texts for a variety of purposes; monitoring the \\
\hline
\end{tabular}


monitoring the writing process, from "draft" to $\quad$ write process, from "draft" to "goodprint".

"good print"

Another method applied in the research was the knowledge questionnaire related to "Communication in Sports" (Table 2), initially applied was the same as that applied at the end, so as to follow the students' progress as a whole, the evolution and its mobility in the practical studies conducted in seminars and in individual student work.

Table 2. Knowledge questionnaire on "Communication in sports" initially / final applied

\begin{tabular}{|l|l|}
\hline \multicolumn{1}{|c|}{ Questions } & \multicolumn{1}{|c|}{ Categoriesofresponses } \\
\hline $\begin{array}{l}\text { 1. Which of the following statements are } \\
\text { you agree to? }\end{array}$ & A) Most members of our team are dedicated professionals \\
& B) In our team are different people \\
C) I do not like many things
\end{tabular}

The scores obtained in this questionnaire, when compared, give a view of the moments of the diagnosis and progress made or stagnation. As a result of applying the initial questionnaire, we found that approximately $57 \%$ of the students obtained a minimum score of 1 or 3 points, $25 \%$ of the students obtained average scores of 3 to 6 points and the difference of $18 \%$ achieved the maximum score between 6-10 points. This shows a poor knowledge of communication concepts as well as a low level of communication skills in different situations. The results obtained in the final evaluation by applying the same questionnaire, following the practical content of the 


\section{THE ANNALS OF "DUNAREA DE JOS" UNIVERSITY OF GALATI \\ FASCICLE XV ISSN - 1454 - 9832 - Vol. 2/2019}

" Management of Communication in Physical Education and Sports" curriculum, in the seminars and individual work of the students, reveals that a significant percentage of students, $71 \%$, succeed in obtaining high scores ranging from $6-10$ points, the other $29 \%$ achieving scores of 1-6 points, proving that throughout the year the students gained important knowledge in the field of communication and developed their communication skills. Each student managed to communicate easily inside the team, but also with people outside the institution. Figure 1 shows the dynamics of the score obtained by the students after applying the final questionnaire compared to the initial stage.

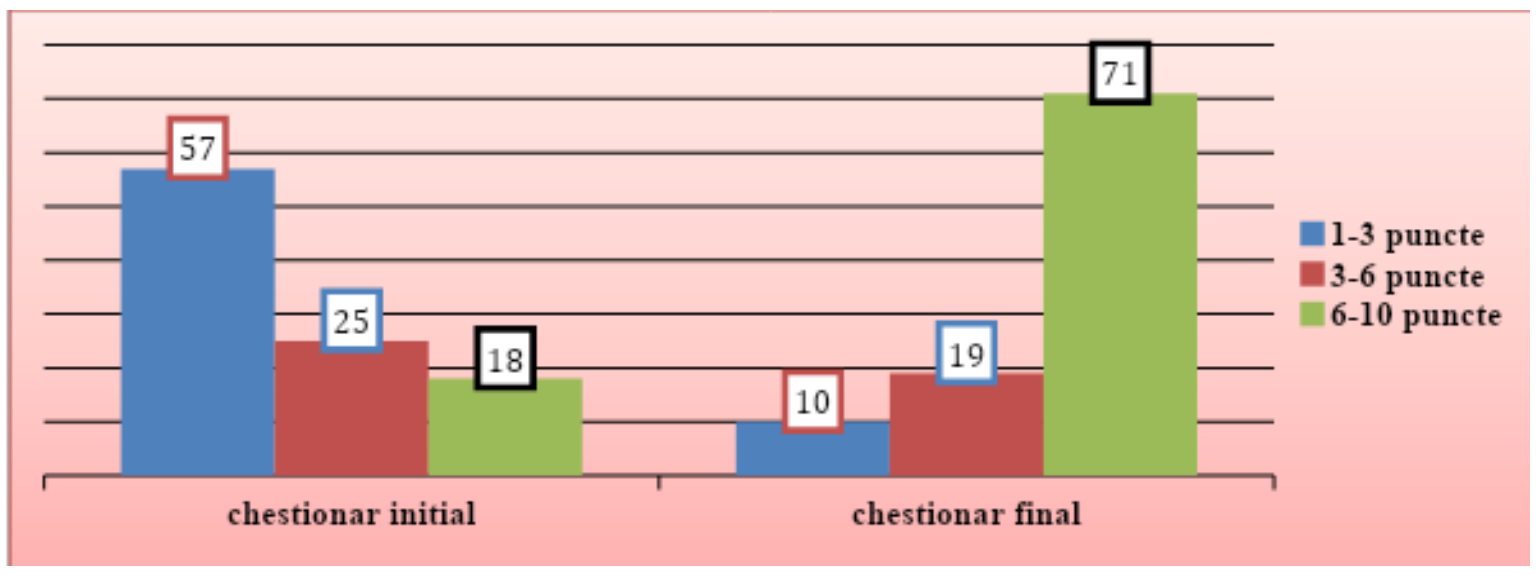

Figure 1. Dynamics of the score obtained by the students after applying the final questionnaire compared to the initial questionnaire

The observation scale was the tool that focused on two components: student behavior and didactic communication. The observation was the method used to study each individual student, but also for the collective seen as a whole, throughout the research. Through this method, we have tracked to what extent students have achieved the expected results. The completion of the observation scales was carried out during 15 hours of seminar and 30 hours of individual work, for each behavior and for each student. The final frequency of behavior is given by the sum of the number of individual manifestations of the respective behavior for each student in relation to the maximum number of possible manifestations.

Table 3. Dynamics of the score obtained by students

\begin{tabular}{|l|l|c|c|c|c|c|c|}
\hline \multirow{2}{*}{$\begin{array}{l}\text { No. } \\
\text { crt. }\end{array}$} & \multirow{2}{*}{$\begin{array}{c}\text { InitialSt } \\
\text { udent }\end{array}$} & $\begin{array}{c}\text { Participates } \\
\text { on its own } \\
\text { initiative in } \\
\text { theplanneda } \\
\text { ctivities }\end{array}$ & $\begin{array}{c}\text { Solves the } \\
\text { problems } \\
\text { marked out by } \\
\text { the teacher }\end{array}$ & $\begin{array}{c}\text { Forms } \\
\text { additional } \\
\text { questions for } \\
\text { clarification }\end{array}$ & $\begin{array}{c}\text { Manifests the } \\
\text { willingness to } \\
\text { help } \\
\text { colleagues in } \\
\text { solving the } \\
\text { tasks }\end{array}$ & $\begin{array}{c}\text { Assists } \\
\text { critical } \\
\text { thinking in } \\
\text { solving tasks }\end{array}$ & $\begin{array}{c}\text { Sends } \\
\text { messages } \\
\text { listens the } \\
\text { colleagues } \\
\text { carefully, by } \\
\text { telling his/her } \\
\text { point of view }\end{array}$ \\
\hline 1. & AA & $\mathbf{1 6}$ & $\mathbf{2 7}$ & $\mathbf{1 1}$ & $\mathbf{2 4}$ & $\mathbf{9}$ & $\mathbf{1 3}$ \\
\hline 2. & BM & $\mathbf{1 2}$ & $\mathbf{3 1}$ & $\mathbf{9}$ & $\mathbf{2 7}$ & $\mathbf{1 0}$ & $\mathbf{1 1}$ \\
\hline 3. & BG & $\mathbf{1 8}$ & $\mathbf{2 9}$ & $\mathbf{1 0}$ & $\mathbf{2 5}$ & $\mathbf{8}$ & $\mathbf{1 0}$ \\
\hline 4. & BV & $\mathbf{1 9}$ & $\mathbf{3 0}$ & $\mathbf{8}$ & $\mathbf{2 9}$ & $\mathbf{7}$ & $\mathbf{7}$ \\
\hline 5. & CV & $\mathbf{1 7}$ & $\mathbf{2 8}$ & $\mathbf{1 1}$ & $\mathbf{2 6}$ & $\mathbf{9}$ & $\mathbf{9}$ \\
\hline 6. & CT & $\mathbf{1 5}$ & $\mathbf{3 0}$ & $\mathbf{9}$ & $\mathbf{2 8}$ & $\mathbf{1 0}$ & $\mathbf{8}$ \\
\hline 7. & EC & $\mathbf{1 9}$ & $\mathbf{3 1}$ & $\mathbf{8}$ & $\mathbf{2 6}$ & $\mathbf{7}$ & $\mathbf{9}$ \\
\hline 8. & GO & $\mathbf{1 6}$ & $\mathbf{2 7}$ & $\mathbf{1 1}$ & $\mathbf{2 7}$ & $\mathbf{8}$ & $\mathbf{1 1}$ \\
\hline 9. & LR & $\mathbf{1 9}$ & $\mathbf{2 5}$ & $\mathbf{9}$ & $\mathbf{2 4}$ & $\mathbf{1 0}$ & $\mathbf{1 3}$ \\
\hline 10. & MS & $\mathbf{1 8}$ & $\mathbf{3 0}$ & $\mathbf{1 0}$ & $\mathbf{2 8}$ & $\mathbf{7}$ & $\mathbf{7}$ \\
\hline 11. & NA & $\mathbf{1 2}$ & $\mathbf{3 1}$ & $\mathbf{9}$ & $\mathbf{2 7}$ & $\mathbf{1 0}$ & $\mathbf{1 1}$ \\
\hline 12. & PM & $\mathbf{1 6}$ & $\mathbf{2 7}$ & $\mathbf{1 1}$ & $\mathbf{2 4}$ & $\mathbf{9}$ & $\mathbf{1 3}$ \\
\hline 13. & SM & $\mathbf{1 9}$ & $\mathbf{2 5}$ & $\mathbf{1 0}$ & $\mathbf{2 6}$ & $\mathbf{9}$ & $\mathbf{1 1}$ \\
\hline 14. & SV & $\mathbf{1 5}$ & $\mathbf{3 0}$ & $\mathbf{9}$ & $\mathbf{2 8}$ & $\mathbf{1 0}$ & $\mathbf{8}$ \\
\hline
\end{tabular}




\section{THE ANNALS OF "DUNAREA DE JOS" UNIVERSITY OF GALATI \\ FASCICLE XV ISSN - 1454 - 9832 - Vol. 2/2019}

Through the analysis of behaviors we noticed that the majority of students solve the problems outlined by the teacher, showing willingness to help colleagues in solving tasks. They are also able to send messages, listen to each other, formulate questions and answer questions, argue an answer, make a decision. Student-facing communication reflects an appropriate tone, convincing gestures and self-mastery. The data obtained show good communication in the teaching activity, a high interest from the students for the practical study, those who are actively involved in the learning process.

Verification of the students' knowledge was done throughout the semester during the seminars, so that by carrying out the current evaluation and applying the knowledge tests, they were able to get positive results in this respect. Thus, we applied two tests, which had the same degree of difficulty, and which included the knowledge gained through the contents of the learning units.

In order to solve the evaluation tests correctly, the students used the knowledge acquired in the learning situations proposed in the units of the course " Management of Communication in Physical Education and Sports". Thus, students have been able to associate and use acquired knowledge, integrate them into knowledge systems, combine them, demonstrate creativity and originality in solving didactic tasks. At the same time, we have found that students have more easily formulated the answer to the questions, in an original way by approaching critical thinking, could interpret the content of a document in a personal manner, and develop new solutions to solve a given issue.

Thus, the results obtained following the application of the two evaluation tests confirm that there is a visible progress in the accumulation of knowledge by the students, which indicates that they manage to apply them in different new situations, communicate them efficiently, exercising at the same time the communication skills. In Table 3.10 we reflect the scores obtained by the students in the two tests.

Table 4. Score obtained by students

\begin{tabular}{|c|c|c|c|c|}
\hline \multirow{2}{*}{ Score } & \multicolumn{2}{|c|}{ Test 1 } & \multicolumn{2}{c|}{ Test 2 } \\
\cline { 2 - 5 } & No. of Students & $(\%)$ & No. of Students & $(\%)$ \\
\hline 1-25 - Insufficient & 0 & & 0 & \\
\hline $\mathbf{2 5 - 5 0}$ - Sufficient & 1 & 7.14 & 1 & 7.14 \\
\hline $\mathbf{5 0 - 7 5}$ - Good & 4 & 28,57 & 3 & 21,42 \\
\hline $\mathbf{7 5 - 1 0 0}$ - Very good & 2 & 14,28 & 2 & 14,28 \\
\hline
\end{tabular}

According to the data obtained in Table 4 we can see that $7,14 \%$ of the students obtained a score ranging from 25 to 50 points respectively a sufficient score; a percentage ranging from 21.41 to $28.57 \%$ score scored by the students on the applied tests, with a good score, while $14.28 \%$ scored in the percentage value of $75-100$ points.
In Table 5 we present the dynamics of the score obtained by the studentsas a result of their assessment by the expert group on the basis of the individual activities of the students conducted in the seminars and the individual work, respectively the work carried out and based on the drawn up portfolio, including by applying the knowledge tests as well.

Table 5. Dynamics of the score obtained by the students $(n=14)$

\begin{tabular}{|c|c|c|c|c|c|c|}
\hline $\begin{array}{l}\text { No. } \\
\text { crit }\end{array}$ & $\begin{array}{c}\text { tests } \\
\text { Behaviour }\end{array}$ & $\begin{array}{l}\text { Group } \\
\text { And } \\
\text { Statistics }\end{array}$ & $\begin{array}{c}\text { Initial indicators } \\
\bar{X} \pm m\end{array}$ & $\begin{array}{l}\text { Final indicators } \\
\bar{X} \pm m\end{array}$ & $\mathbf{t}$ & \\
\hline \multirow{4}{*}{1} & \multirow{4}{*}{$\begin{array}{l}\text { Participates on } \\
\text { its own } \\
\text { initiative in the } \\
\text { planned } \\
\text { activities }\end{array}$} & $\mathbf{M}$ & $16.50 \pm 0.55$ & $17.12 \pm 0.53$ & $1.24>$ & 0.05 \\
\hline & & $\mathbf{E}$ & $16.70 \pm 0.52$ & $18,61 \pm 0,48$ & 4,15 & $<0,01$ \\
\hline & & $\mathbf{t}$ & 0,26 & 2,10 & - & - \\
\hline & & $\mathbf{P}$ & $>0,05$ & $<0,05$ & - & - \\
\hline \multirow{4}{*}{2} & \multirow{4}{*}{$\begin{array}{l}\text { Solves the } \\
\text { problems } \\
\text { marked out by } \\
\text { the teacher }\end{array}$} & $\mathbf{M}$ & $28,64 \pm 0,47$ & $29,12 \pm 0.44$ & 1.14 & $>0.05$ \\
\hline & & $\mathbf{E}$ & $28.85 \pm 0.46$ & $30.37 \pm 0.41$ & 3.80 & $<0.01$ \\
\hline & & $\mathbf{t}$ & 0.32 & 2.08 & - & - \\
\hline & & $\mathbf{P}$ & $>0.05$ & $<0.05$ & - & - \\
\hline \multirow{3}{*}{3} & \multirow{3}{*}{$\begin{array}{l}\text { Forms } \\
\text { additional } \\
\text { questions for }\end{array}$} & $\mathbf{M}$ & $9.64 \pm 0.23$ & $9.89 \pm 0.22$ & 1.19 & $>0.05$ \\
\hline & & $\mathbf{E}$ & $9.71 \pm 0.24$ & $10.44 \pm 0.20$ & 3,65 & $<0,01$ \\
\hline & & $\mathbf{t}$ & 0,21 & 2,13 & - & - \\
\hline
\end{tabular}


THE ANNALS OF "DUNAREA DE JOS" UNIVERSITY OF GALATI

FASCICLE XV ISSN - 1454 - 9832 - Vol. 2/2019

\begin{tabular}{|c|c|c|c|c|c|c|}
\hline & clarification & $\mathbf{P}$ & $>0,05$ & $<0,05$ & - & - \\
\hline \multirow{4}{*}{4} & \multirow{4}{*}{$\begin{array}{l}\text { Manifests the } \\
\text { willingness to } \\
\text { help colleagues } \\
\text { in solving the } \\
\text { tasks }\end{array}$} & $\mathbf{M}$ & $26,36 \pm 0,3926,79$ & $\pm 0,38$ & 1,23 & $>0,05$ \\
\hline & & $\mathbf{E}$ & $26,40 \pm 0,39$ & $27,91 \pm 0,36$ & 4,31 & $<0,001$ \\
\hline & & $\mathbf{t}$ & 0,07 & 2,15 & - & - \\
\hline & & $\mathbf{P}$ & $>0,05$ & $<0,05$ & - & - \\
\hline \multirow{4}{*}{5} & \multirow{4}{*}{$\begin{array}{l}\text { Assists critical } \\
\text { thinking in } \\
\text { solving tasks }\end{array}$} & $\mathbf{M}$ & $8,78 \pm 0,23$ & $9,03 \pm 0,22$ & 1,19 & $>0,05$ \\
\hline & & $\mathbf{E}$ & $8,88 \pm 0,24$ & $9,66 \pm 0,20$ & 3,90 & $<0,01$ \\
\hline & & $\mathbf{t}$ & 0,30 & 2,10 & - & - \\
\hline & & $\mathbf{P}$ & $>0,05$ & $<0,05$ & - & - \\
\hline \multirow{4}{*}{6.} & \multirow{4}{*}{$\begin{array}{l}\text { Sends messages } \\
\text { and listens the } \\
\text { colleagues } \\
\text { carefully, by } \\
\text { telling his/her } \\
\text { point of view }\end{array}$} & $\mathbf{M}$ & $10,07 \pm 0,47$ & $10,51 \pm 0,45$ & 1,05 & $>0,05$ \\
\hline & & $\mathbf{E}$ & $10,19 \pm 0,46$ & $11,83 \pm 0,41$ & 4,10 & $<0,01$ \\
\hline & & $\mathbf{t}$ & 0,18 & 2,16 & - & - \\
\hline & & $\mathbf{P}$ & $>0,05$ & $<0,05$ & - & - \\
\hline
\end{tabular}

Note: $\mathrm{n}-14 ; \mathrm{P}-0,050,010,001 \mathrm{r}-0,576$

$\mathrm{f}=13 \mathrm{t}-2,1603,0124,221$

$\mathrm{f}=26 \mathrm{t}-2,0562,7793,707$

In the test one (ifparticipates on its own initiative in the planned activities), initially the control group recorded a score of $16.50 \pm 0.55$; and in the final test $17,12 \pm 0,53 ; \mathbf{t}$ being 1.24 and $\mathbf{p}>0.05$. The experimental group recorded values of $16.70 \pm 0.52$ close to the control group in the initial testing, the final score averaged 18.61 \pm 0.48 with $\mathbf{t}$ being 4.15 and $\mathbf{p}<0.01$ significant value, demonstrating that the new course focused on the holistic model and adequate guiding skills has reached its goal. The score recorded by the control group in testing on sending the messages and listening to the colleagues constituted in the initial testing an average of $10.07 \pm 0.47$ and in the final $10.51 \pm 0.45$ and $\mathbf{t}$ is 1.05 with $\mathbf{p}>0.05$; the experimental group recorded an average of $10.19 \pm$ 0.46 points $\mathbf{t}$ being 4.10 and $\mathbf{p}<0.01$ also significant value. From the data obtained and reflected in Table 5, as a whole, we can mention that the activities carried out in the practical seminars have contributed to the development of the students' communication skills and to the achievement of the expected competencies.

In conclusion, we can mention that by applying the integrated curriculum in higher education of physical education and sport, prerequisites are created for transdisciplinarity. The development of practical studies in the seminars and in the individual work of students, through the use of a modern, interactive learning vision, determines the formation of the students' communication skills, the positive interpersonal relation and the improvement of the academic achievements and success in the subject of "Management of Communication in physical education and sports". Thus, students collaborate in groups, help each other, enjoying the successes obtained collectively or individually, and understand and assume roles depending on context and personal skills. At the same time, by applying the holistic model of teaching and learning the theoretical course in the higher education in the field, specialized practical skills are formed and developed, contributing to the development of students' organizational spirit and critical thinking, their effective communication in various forms (verbal, with the use of specialized, non-verbal terminology) and, last but not least, it ensures the awareness of the situations or ways in which individual decisions can affect their own person, the group to which the community belongs.

\section{References}

1. Gîdei M., Budevici-Puiu A., Particularities of effective communication in sports activities. In: Sports. Olympism. Health: The Materials of the International Scientific Congress. Volume I. Chişinău: USEFS, 2016, p. 65-70.

2. Grimalschi T., Openness to the Impact of New Trends in Developing Specific Communication Skills in School Physical Education. In: Theory and Art of Physical Education in School, 2014, No.3, pp. 29-32.

3. Oprișan V., Marketing and Communication in Sport. Bucharest: Uranus, 2002

4. Popescu D., The art of communicating. [monograph]. Bucharest: Ed. Economică, 1998.

5.Văideanu G., Millennium Border Education, Political Publishing House, Bucharest 1998. 